\title{
Samorząd - zmiany ewolucyjne czy rewolucyjne? Recenzja monografii dr. Krzysztofa Gawkowskiego pod tytułem Administracja samorządowa w teorii i praktyce, Toruń 2017, ss. 276
}

W 2017 r. ukazała się nakładem Wydawnictwa Adam Marszałek w Toruniu monografia naukowa Krzysztofa Gawkowskiego pod tytułem Administracja samorządowa $w$ teorii $i$ praktyce, Torun 2017, ss. 276. Tytuł monografii sugeruje potencjalnemu czytelnikowi, przeglądającemu zasób biblioteki lub księgarni, charakter podręcznikowy lub nawet skryptowy omawianej pracy. Jednak nic bardziej mylącego, recenzowana książka jest bowiem nowatorską syntezą, łączącą w sobie teoretyczną analizę zagadnień dotyczących polskiego samorządu terytorialnego z prezentacją praktyki jego funkcjonowania. Monografia wskazuje również na dysfunkcje i dobre praktyki w samorządach oraz aktualne tendencje rozwojowe w działalności jednostek samorządu terytorialnego.

Rozważania dotyczące obecnie przyjętego modelu samorządu terytorialnego w Polsce autor poprzedza analizą historyczną zjawiska samorządności, która płynnie przechodzi w opis procesów społecznych tworzących i towarzyszących temu zjawisku. Jest to wprowadzenie, które określa czynniki legitymizujące istnienie i funkcje współczesnych upodmiotowionych wspólnot samorządowych. Autor wyjaśnia w ten sposób obecną organizację i zasady funkcjonowania samorządu terytorialnego, które mają historyczne podłoże. Uzupełnia jednocześnie treść o rozważania po pierwsze nad decentralizacją władzy, po wtóre nad partycypacją społeczną. Wielu autorów podobnych prac nie poświęca tak wiele miejsca kwestii decentralizacji będącej elementem urzeczywistnienia idei państwa obywatelskiego. Zatrzymują się raczej na analizie prawnej i rozwodzą nad samą definicją ustrojową decentralizacji, jej umocowaniem konstytucyjnym czy nawet hierarchią organów władzy publicznej. Tymczasem K. Gawkowski kładzie nacisk na oddzielenie pojęcia rządzenia (lokalnego) od samorządności, na wsparcie jednostki w relacji $\mathrm{z}$ władzą samorządową oraz tworzenie wa-

\footnotetext{
${ }^{1}$ Dr Łukasz Kozera, Wyższa Szkoła Ekonomii, Prawa i Nauk Medycznych im. prof. Edwarda Lipińskiego w Kielcach.
} 
runków realnej decentralizacji i szerokiej partycypacji społecznej. Partycypacji nie analizuje wyłącznie pod kątem współdecydowania obywateli w procesie kształtowania budżetów obywatelskich, choć słusznie wskazuje, że jest to jej najwyższa forma. Bada także istniejące obowiązki konsultacji społecznych. Daje przy tym praktyczne porady, jak osiągnąć efektywność w trakcie zaciągania opinii obywateli. Oprócz uwag technicznych wskazuje zakres podmiotowy i przedmiotowy konsultacji, który może wpływać lub służyć zakładanemu celowi - uzyskaniu wiedzy, opinii lub nawet wytycznych co do dalszego postępowania władz samorządu. Rozważania powyższe są czymś w rodzaju prologu do dalszych części książki. W licznych jej fragmentach autor wraca bowiem do udziału społeczeństwa w sprawowaniu władzy i urzeczywistnianiu teorii wspólnoty lokalnej, która sama dla siebie jest najlepszym i najskuteczniejszym regulatorem.

W recenzowanej książce K. Gawkowski dokonuje podsumowania dotychczasowych doświadczeń $\mathrm{w}$ funkcjonowaniu samorządu, sugerując jednocześnie, że są one nieco inne w przypadku gminy, powiatu i regionu. Uznaje, że samorząd gminny, jako działający na bazie sprawdzonych modeli, jest najbardziej stabilny i generalnie ocenia go pozytywnie. Nie krytykuje przy tym powiatu, co ostatnio stało się trendem $\mathrm{w}$ opracowaniach naukowych i publicystyce. Widzi jednak szereg wyzwań stojących przed samorządem i wskazuje potrzebę wprowadzenia nowoczesnych instrumentów zarządzania i racjonalizacji finansów. Domaga się wręcz urzeczywistnienia koncepcji inteligentnych miast. Autor widzi konieczność prowadzenia nowego rodzaju polityk, jak choćby tzw. polityki senioralnej, a co się z tym wiąże - przewartościowania funkcji i celów służby zdrowia i pomocy społecznej nie tylko w aspekcie organizacyjnym, ale i w wymiarze społeczno-ekonomicznym.

Cenne postulaty, które mogą być uwzględnione również w praktyce działania samorządu terytorialnego, autor formułuje $\mathrm{w}$ rozdziale piątym. Są one kierowane głównie do gmin. Nie oznacza to, że niektóre trafne rozwiązania, np. crowfunding jako metoda pozyskania środków finansowych na konkretne projekty lokalne, nie mogą być wykorzystywane przy realizacji zadań powiatu czy województwa. Przeciwnie - niektóre innowacyjne pomysły czy systemy inwestycyjne muszą mieć charakter co najmniej regionalny, aby przynosiły korzyści osobom wspierającym projekt, bez względu na to, czy korzyści te będą polegać na rozwoju jakiejś idei czy też podmiot wspierający (społeczność) otrzyma jakiś wymierny udział w zyskach. Autor pokazuje wybrane przez siebie rodzaje dobrych praktyk na przykładzie gminy miejskiej. Jest to podejście użyteczne, gdyż czytelnik zaznajamia się z nowymi sposobami zarządzania publicznego w sposób prosty i przejrzysty. Książka przeznaczona jest dla szerokiego odbiorcy. Szkoda wiec, że punktując patologie i dysfunkcje w samorządach, autor nie czyni tego na podstawie konkretnych przykładów. $Z$ pewnością ma on potencjał naukowy, aby przeprowadzić odpowiednie badania i dokonać ich analizy. 
Z rozważań K. Gawkowskiego wynika, że gmina to podmiot, który jest najbardziej narażony na destrukcyjne konflikty interesów, korupcję okrytą lokalną zmową milczenia i tzw. ufirmowienie. To ostatnie zjawisko jest powszechne nawet w małych gminach wiejskich. Wójtowie i radni, często wybierani głosami rodzin i klienteli urzędu, traktują gminę jak swoją własną firmę, mającą służyć ugruntowaniu ich wpływów i dochodów. Takiemu folwarcznemu traktowaniu samorządu zapobiec może jedynie ograniczenie kadencji włodarzy gmin. Czym innym są patologie organizacyjne, które wyeliminować można niekiedy zmieniając prawo, częściej jednak istotne znaczenie będzie tu miał czynnik ludzki. Remedium na ten stan rzeczy jest profesjonalizacja kadr, przestrzeganie procedur administracyjnych i etycznych oraz stałe zwiększanie kompetencji urzędników. Ważna jest też należyta gratyfikacja finansowa za pracę w administracji samorządowej, która wpłynie na rzetelność zawodową. Zwiększy się wówczas poziom przestrzegania procedur i odporności na korupcję. Powyższe problemy wcale nie mają podobnego wymiaru, ilościowego i jakościowego, na szczeblu gminy, powiatu czy województwa. Wyliczając lub nawet próbując definiować te zjawiska, autor nie powinien skupiać się tylko na gminie. Należy tutaj zgodzić się z K. Gawkowskim, że nowa formuła wyborów i dwukadencyjność może w przyszłości zupełnie zmienić życie polityczne samorządu. Można także założyć, że nadchodzące ograniczenie regionów w gospodarowaniu środkami unijnymi pozytywnie wpłynie na niezdrowe klientelistyczne relacje pomiędzy samorządami, co w dużej mierze podważy realną hierarchię pomiędzy nimi. Dostrzegane przez autora zmiany mają charakter ewolucyjny. Tymczasem czytając Administrację samorzadowa w teorii i praktyce, można dojść do przekonania, że w samorządzie terytorialnym konieczne są raczej zmiany rewolucyjne, których wprowadzenia autor jednak nie proponuje. Konieczny jest punkt zwrotny, który spowoduje zmianę myślenia o samorządzie i ukierunkuje energię wspólnot lokalnych na nowe trendy, które już dziś wskazuje Krzysztof Gawkowski. Zakończyło się bowiem zasypywanie luki infrastrukturalnej, a przed samorządem stoją takie problemy jak kryzys demograficzny, inwestycje w energię odnawialną czy rozwój mieszkalnictwa socjalnego. Faktem też jest, że niektórych starych programów społecznych samorządy nie zrealizowały należycie. Z pewnością zaliczyć do nich można edukację, służbę zdrowia na szczeblu powiatu, aktywizację zawodową czy walkę z wykluczeniem społecznym. Samorządy w dotychczasowej formule nie zdołają nigdy sprostać tym zadaniom. Potrzebna jest zmiana polegająca na rozszerzeniu ich zaplecza, wzmocnieniu potencjału i zapewnieniu efektu skali w działaniu. Niektóre małe gminy i powiaty doskonale sprawdziły się, rozwijając lokalną infrastrukturę drogową, wodociągową lub rekreacyjną. Ale żeby zmierzyć się z kryzysem demograficznym, zadłużeniem służby zdrowia i organizacją edukacji na należytym poziomie, warto pomyśleć o zmianach ustrojowo-organizacyjnych. 
Podobnie rzecz się ma w przypadku co najmniej regionów. Nie można bowiem łudzić się, że wszystkie polskie województwa posiadają odpowiednie uwarunkowania geograficzne, kapitał ludzki czy inne rzeczywiste kapitały, aby sprostać przyszłym problemom. Do tego dochodzą coraz większe aspiracje cywilizacyjne mieszkańców. Tymczasem rola samorządu marszałkowskiego jako dysponenta środków unijnych powoli dobiega końca. Zmianą rewolucyjną może więc być choćby częściowa reforma podziału terytorialnego państwa, mająca na celu zmniejszenie zbyt dużej liczby gmin, powiatów i województw. Nie jest to zadanie łatwe i z pewnością wymaga odwagi politycznej ustawodawcy, ale w perspektywie najdalej dekady wydaje się konieczne. Reforma ta jest potrzebna nie po to, by samorządy stały się ekonomicznie wydajne, takie bowiem podejście słusznie krytykuje Krzysztof Gawkowski, ale by skutecznie i efektywnie służyły nam wszystkim. 